\title{
Investigation of gene effects on Fruit Shape Index and Seed Size in Generations Resulting from The Crossing of Zucchini and Hull-Less Seed Pumpkin
}

\section{Sima Davoodi}

Guilan University Faculty of Agriculture

Jamal-Ali Olfati ( $\sim$ jamalaliolfati@gmail.com )

Guilan University Faculty of Agriculture https://orcid.org/0000-0002-5485-8884

\section{Babak Rabiei}

Guilan University Faculty of Agriculture

\section{Atefeh Sabouri}

Guilan University Faculty of Agriculture

\section{Research Article}

Keywords: Cucurbita pepo var. styriaca, Cucurbita pepo var. pepo, Additive effect, Dominant effect, Epistasis, Generation mean analysis

Posted Date: June 22nd, 2021

DOl: https://doi.org/10.21203/rs.3.rs-590556/v1

License: (c) (i) This work is licensed under a Creative Commons Attribution 4.0 International License. Read Full License

Version of Record: A version of this preprint was published at Euphytica on August 18th, 2021. See the published version at https://doi.org/10.1007/s10681-021-02911-y. 


\section{Investigation of gene effects on fruit shape index and seed size in generations resulting from the} crossing of Zucchini and hull-less seed Pumpkin

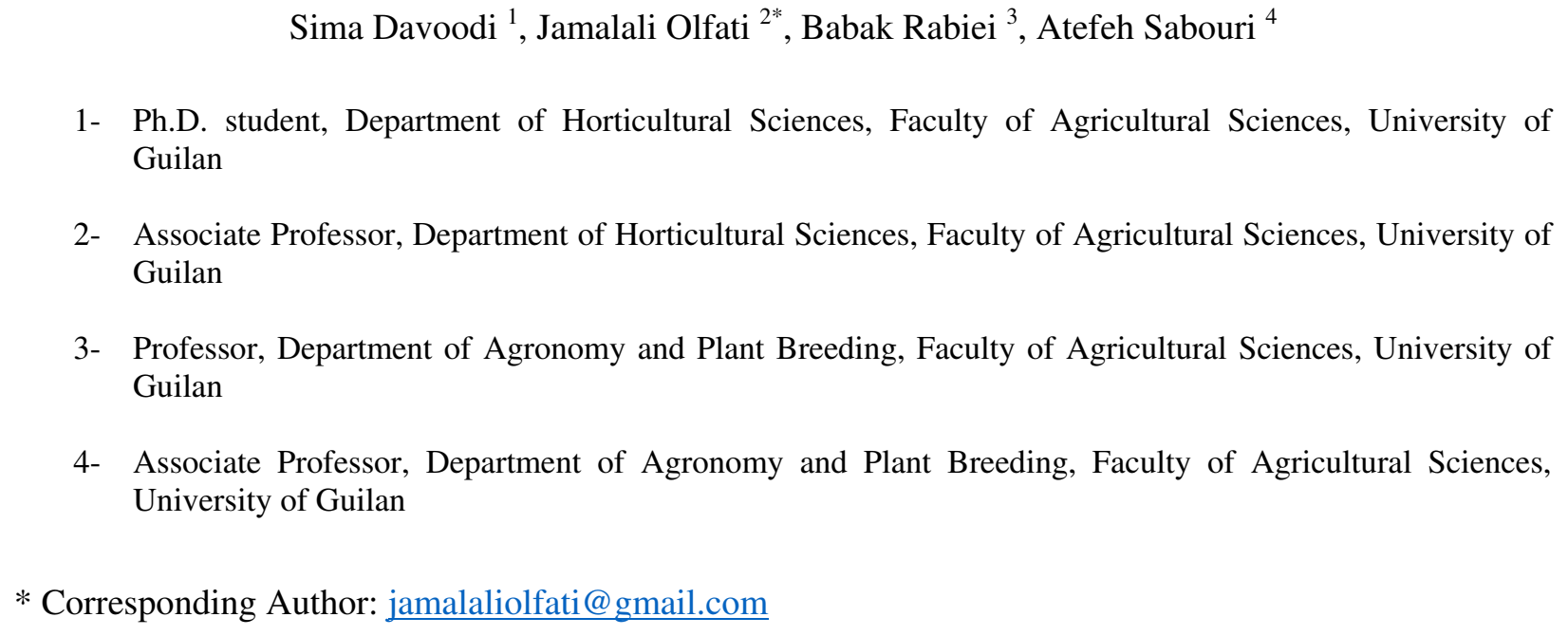

3- Professor, Department of Agronomy and Plant Breeding, Faculty of Agricultural Sciences, University of Guilan

4- Associate Professor, Department of Agronomy and Plant Breeding, Faculty of Agricultural Sciences, University of Guilan

* Corresponding Author: jamalaliolfati@gmail.com

\section{Abstract}

Fruit shape index (round shape) and seed size have important effects on pumpkin yield. To investigate these traits and create the most desirable state, a cross was made between two pumpkin cultivars. The objective of this study was to estimate the main gene effects (additive, dominant and di-genic epistasis) and to determine the mode of inheritance for fruit shape and seed size by generation mean analysis. Six generations, namely $\mathrm{P}_{1}, \mathrm{P}_{2}, \mathrm{~F}_{1}, \mathrm{~F}_{2}, \mathrm{BC}_{1}$, and $\mathrm{BC}_{2}$ from a cross between Zucchini and hull-less seed Pumpkin, S10 $\times$ P25, were constructed and evaluated for fruit length, fruit width, fruit shape index, and some seed-related traits (seed length, seed width, seed thickness). The experiment was conducted in the research field of the Faculty of Agricultural Science, University of Guilan, Rasht, Iran in 2019. Results showed a significant difference between generations in terms of fruit and seed traits. Scale and joint scale tests showed the presence of epistasis for some traits. According to the results of the average traits of different generations, standard heterosis and hetrobeltiosis were observed. Concerning the fruit shape index and seed width, there was an over-dominance effect. The broad-sense heritability of the traits was relatively high for all traits and between 52 and 92\%. Narrow sense heritability was between 26 and $86 \%$ and relatively low for the fruit shape index and seed width. Therefore, selection of elite lines and production of their hybrids are recommended as two methods suitable for breeding to achieve the round shape index and larger seed size.

Keywords: Cucurbita pepo var. styriaca, Cucurbita pepo var. pepo, Additive effect, Dominant effect, Epistasis, Generation mean analysis 


\section{Introduction}

Pumpkin is a plant of the Cucurbitaceae family, which according to the latest classification statistics includes 118 genera and 825 species (Jeffrey et al. 1990). In Cucurbita, five cases of $C$. argyrosperma, C. ficifolia, C. maxima, C. moschata, and C. pepo have been domesticated (Schaefer and Renner 2011). Pumpkin has a rich and long history in terms of cultivation and domestication and unique diversity in terms of morphological characteristics, particularly the shape of the fruit and has a wide range of adaptation in cultivation (Savage et al. 2015). Pumpkins have a long history of consumption and are used for many purposes, especially for seed. Despite the production of vegetables in Iran and its ranking in terms of production in global markets and due to the area under cultivation and abundant production of these products in the country, thus far, no significant activity has been performed in the field of seed production, and most of the required seeds have been supplied from abroad (Hosseinzadeh and Amjadi Souraki 2012).

Stewed squash (Cucurbita pepo L. var. pepo) is one of the species whose plants have limited growth. The seeds of this squash have a uniform cream color; its leaves are multi-lobed with rough hairs on the leaves. The tail of the fruit is hard, woody, and polygonal (angular). Its flowers are characterized by short, thick, and conical flags (Decker-Walters and Walters 2000). In general, the seeds of the ediblefruited cultivar-groups of $C$. pepo subsp. Pepo (Pumpkin, Vegetable Marrow, Cocozelle, Zucchini) are longer, wider, and thicker than those of other species of C. pepo. (Paris and Nerson 2003).

Hull-less seeded pumpkin (Cucurbita pepo L. var. pepo subsp. styriaca) is a species that has found an important place in the medicine and food industries owing to fatty acids in its seed oil and high protein content (Hosseinzadeh and Amjadi Souraki 2012). It has round fruit and more seeds per fruit. The fruits of hull-less seeded pumpkins are yellowish-orange in color, and the seeds are olive green. One of the most important characteristics of this plant is its skinless seeds (Mitra 2001).

One of the most diverse traits related to squash, which is also important to the consumer, is the shape of the fruit. Fruit shape can vary from round to disc-shaped to very long (Paris 2008). Cucurbita pepo L. is highly polymorphic for fruit shape and size. Fruit shape and size are polygenically controlled, and it has proven difficult to identify individual genes affecting these characteristics (Emerson 1910; Sinnott 1936). Fruit shape is a highly important quantitative trait, which is closely associated with fruit quality. There are no genetic models of fruit shapes (Hazra et al. 2007; Paris and Brown 2005; Wang et al. 2012), and no reports are available on the genetic control of fruit shapes in pumpkins. The analysis of

67 fruit shape using the L/W ratio could be a useful approach to select other characteristics of pumpkin 68 shapes (ketsakul et al. 2020). Seed size is an important trait in a hull-less seeded pumpkin, both from seed 69 yield and consumer acceptance viewpoints. As earlier investigations indicated, the highest seed yields 
could be obtained in small-fruited strains due to the association of fruit size with the seed size (Carle et al. 1994).

The hybrid production method can be used to achieve the desired traits, including fruits with a round shape containing larger seeds. In addition, one of the methods to evaluate the results in hybrids is to use the method of generation average analysis and calculation of genetic parameters. Generation means analysis is an efficient technique to estimate important gene effects, such as additive effects, dominance, and interaction in the development of quantitative traits (Amaefula et al. 2014). Generation means analysis method was developed by Jinks and Jones (1958), Hayman (1958), and Mather and Jinks (1982). In general, knowing nature genes involved in the development of traits act is the first step in advancing breeding goals, so that if most of the gene effects are additive, it is recommended that the breeding process be continued through direct selection for the trait. If the genetic effects are predominant, it is recommended that the breeding route be continued to produce hybrid cultivars (Bernardo 2002; Azizi et al. 2006; Rebolloza 2016).

According to researchers, crosses were made between PI 285611 and a small-fruited hull-less seeded strain (NH29-13-5, F6) with a moderately large seed (av. 14 g per 100) to study the heritability of fruit and seed traits and the relationship between fruit and seed size. Heritability of fruit weight was relatively low (61.7\%). Heritability for seed weight, seed length, and seed thickness was 76.4, 78.7, and $85.2 \%$, respectively. A lower heritability for seed width $(68.1 \%)$ can probably be due to the effect of different degrees of expression of the hull-less trait on seed coat development along the seed margins. heritability (NSH), and dominance degree for some fruit characteristics (fruit length, fruit diameter, and average fruit weight) in summer squash. Broad sense heritability estimates were moderate to high for the studied traits. Narrow sense heritability was low for the studied characteristics. Over dominance controlled the inheritance of the studied traits. Narrow sense heritability was low and valued 13\% (fruit length), $21 \%$ (fruit diameter) and 27\% (average fruit weight).

Paris and Nerson (2003) investigated the seed samples of 174 accessions of Cucurbita pepo for the seed length, width, and thickness. They revealed that the mean seed length ranged from 8.8 to 23.3 $\mathrm{mm}$, the mean seed width from 5.0 to $12.5 \mathrm{~mm}$, and the mean seed thickness from 1.2 to $3.8 \mathrm{~mm}$. The

101 length-to-width ratio ranged from 1.5 to 2.5 , the length-to-thickness ratio from 3.7 to 8.2 , and the width-

102 to-thickness ratio from 2.0 to 4.9. Based on the results in C. pepo, seed size is positively associated with 103 fruit size, and seed shape is inversely associated with fruit shape. 

pumpkin species having a round shape in terms of fruit shape and a longer length, width and thickness in terms of seed quality. Therefore, appropriate methods should be employed to improve the traits to be determined by examining the effect of the desired genes. Materials and methods:

Zucchini and hull-less seeded Pumpkin pure lines (P25 and S10) were selected for hybridization to improve fruit shape (round) and seed size (large). Field experiments to generate populations and record field data were performed during three consecutive planting seasons in the spring and summer of 2017-

1122019 in the research field of the Faculty of Agricultural Sciences, University of Guilan, Rasht, Iran. In the 113 first year, two parental lines, Pumpkin (S10) and Zucchini (P25), which were previously purified by 114 Davoodi et al. (2015), were crossed to produce the seeds of the first generation $\left(\mathrm{F}_{1}\right)$. At this stage, the 115 field cultivation system was considered in rows, and planting distance of two meters between rows and one meter on the rows (Sajed et al. 2002; Elizabeth 2001; Latifi et al. 2012) and the steps were performed by implementing the drip irrigation system, using cover mulch, and exercising necessary and appropriate care in all stages of growth. In the second year, $F_{1}$ seeds were planted in the field and were self-pollinated to produce second-generation seeds $\left(\mathrm{F}_{2}\right)$. Furthermore, many other $\mathrm{F}_{1}$-generation plants were backcrossed with both parental lines to produce backcrossing generations $\left(\mathrm{BC}_{1}\right.$ and $\left.\mathrm{BC}_{2}\right)$. In the third year, the seeds of the six generations, including two parental lines $\left(\mathrm{P}_{1}\right.$ and $\left.\mathrm{P}_{2}\right)$, along with $\mathrm{F}_{1}, \mathrm{~F}_{2}, \mathrm{BC}_{1}$ and $\mathrm{BC}_{2}$ were cultivated in a randomized complete block design with three replications in the research field of the Faculty of Agricultural Sciences, University of Guilan, Rasht, Iran. The desired traits, such as fruit length, fruit width, fruit shape index, seed length, seed width, and seed thickness were measured. Length along the axis of each fruit from the place of the peduncle to the tail of the fruit and width at the equatorial region of the fruit were measured. Measurements were performed on each seed using a digital caliper based on millimeters. Seed length along the seed axis, seed width from the widest part of the seed, and seed thickness from the thickest part of the seed were considered.

Random samples were selected from each generation, so that from each parent and the first generation, 10 plants per replication and 30 plants, and from each of the backcrosses and the second generation 30 plants per replication and 90 plants, were considered.

To analyze the data and evaluate the genetic effects of controlling the studied traits, the method employed by Mather and Jinks (1982) according to Equation (1) was used:
(1) $\mathrm{Y}=\mathrm{m}+\alpha[\mathrm{d}]+\beta[\mathrm{h}]+\alpha^{2}[\mathrm{i}]+2 \alpha \beta[\mathrm{j}]+\beta^{2}[1]$

Where $\mathrm{Y}$ is the mean of one generation, $\mathrm{m}$ is the mean of all generations in a cross, [d], [h], [i], [j] and [1] 136 are the effects of genetic parameters of Mather and Jinks' model (1982) (additive, dominance, additive 
137 xadditive epistasis, additive $\times$ dominance epistasis and dominance $\times$ dominance epistasis, respectively,

138 and $\alpha, \beta, \alpha^{2}, 2 \alpha \beta$ and $\beta^{2}$ are the coefficients of these genetic parameters, respectively). Equations (2) to (5)

139 were used to test the presence of epistatic effects, and t-Student based on equations (6) to (9) was used to

140 test their significance (Mather and Jinks 1982):

141 (2) $\mathrm{A}=2 \overline{\mathrm{BC}}_{1}-\overline{\mathrm{F}}_{1}-\overline{\mathrm{P}}_{1}$

142 (3) $\mathrm{B}=2 \overline{\mathrm{BC}}_{2}-\overline{\mathrm{F}}_{1}-\overline{\mathrm{P}}_{2}$

143 (4) $\mathrm{C}=4 \overline{\mathrm{F}}_{2}-2 \overline{\mathrm{F}}_{1}-\overline{\mathrm{P}}_{1}-\overline{\mathrm{P}}_{2}$

$144 \quad$ (5) $\mathrm{D}=2 \overline{\mathrm{F}} 2-\overline{\mathrm{BC}} 1-\overline{\mathrm{BC}} 2$

(6) $t_{\mathrm{A}}=\frac{\mathrm{A}}{\sqrt{\mathrm{V} \bar{P} 1+\mathrm{V} \bar{F} 1+4 \mathrm{~V} \overline{B C} 1}}$

(7) $t_{B}=\frac{\mathrm{B}}{\sqrt{\mathrm{V} \bar{P} 1+\mathrm{V} \bar{F} 1+4 \mathrm{~V} \overline{B C} 2}}$

(8) $\mathrm{t}_{\mathrm{C}}=\frac{\mathrm{C}}{\sqrt{V \bar{P} 1+V \bar{P} 2+4 \mathrm{~V} \bar{F} 1+16 \mathrm{~V} \bar{F} 2}}$

149 To estimate the effects of genes controlling the studied traits, Equations (10) to (15) were used (Mather 150 and Jinks 1982):

151

152 (10) $\mathrm{m}=0.5 \overline{\mathrm{P} 1}+0.5 \overline{\mathrm{P} 2}+4 \overline{\mathrm{F} 2}-2 \overline{\mathrm{BC} 1}-2 \overline{\mathrm{BC} 2}$

(11) $\mathrm{d}=0.5 \overline{\mathrm{P} 1}-0.5 \overline{\mathrm{P} 2}$

(12) $\mathrm{h}=6 \overline{\mathrm{BC} 1}+6 \overline{\mathrm{BC} 2}-8 \overline{\mathrm{F} 2}-\overline{\mathrm{F} 1}-1.5 \overline{\mathrm{P} 1}-1.5 \overline{\mathrm{P} 2}$

(13) $\mathrm{i}=2(\overline{\mathrm{BC}} 1+\overline{\mathrm{BC}} 2)-4 \bar{F} \overline{2}$

(14) $\mathrm{j}=2(\overline{\mathrm{BC}} 1-\overline{\mathrm{BC}} 2)-\overline{\mathrm{P}} 1+\overline{\mathrm{P}} 2 \quad$ or $\quad \mathrm{j}=2 \overline{B C 1}-\bar{P} 1-2 \overline{B C 2}+\overline{P 2}$

(15) $1=\overline{\mathrm{P}} 1+\overline{\mathrm{P}} 2+2 \overline{\mathrm{F} 1}+4 \overline{\mathrm{F} 2}-4 \overline{\mathrm{BC}} 1-4 \overline{\mathrm{BC}} 2$

To evaluate the best genetic model controlling each of the studied traits, joint scaling tests based on the

159 chi-squared test were used, and the degree of correspondence between the observed and expected means

160 (obtained from the significant values of genetic parameters) of the respective generations were 161 statistically tested.

162 The additive $\left(\mathrm{V}_{\mathrm{D}}\right)$, dominance $\left(\mathrm{V}_{\mathrm{H}}\right)$, and environmental $\left(\mathrm{V}_{\mathrm{E}}\right)$ variance components controlling the 163 phenotypic diversity of each of the studied traits were also calculated based on Equations (16) to (18) 164 (Kearsey and Pooni 1996): 
165

166

167

168

169

170

171

172

173

174

175

176

177

(16) $\mathrm{V}_{\mathrm{D}}=2 \mathrm{~V}_{\mathrm{F} 2}-\left(\mathrm{V}_{\mathrm{BC} 1}+\mathrm{V}_{\mathrm{BC} 2}\right)$

(17) $V_{H}=V_{F 2}-V_{D}-V_{E}$

(18) $\mathrm{V}_{\mathrm{E}}=\frac{1}{3}\left(\mathrm{~V}_{\mathrm{P} 1}+\mathrm{V}_{\mathrm{P} 2}+\mathrm{V}_{\mathrm{F} 1}\right)$

Where $\mathrm{V}_{\mathrm{D}}$ is the additive variance, $\mathrm{V}_{\mathrm{H}}$ is the dominance variance, $\mathrm{V}_{\mathrm{E}}$ is the environment variance, $V_{\overline{P 1}}$ is the first parent variance, $V_{\overline{P 2}}$ is the first parent variance, $V_{\overline{F 2}}$ is the second generation of variance, $V_{\overline{F 1}}$ is the first generation of variance, and $V_{\overline{B C 1}}$ and $V_{\overline{B C 2}}$ are the first and second back-crossing, respectively. To determine the dominance deviations in different gene loci, the mean degree of dominance was estimated based on Equation (19): (Mather and Jinks 1982):

$$
(\mathrm{H} / \mathrm{D})^{1 / 2}=\left({\frac{2 \mathrm{~V}[\mathrm{H}]^{1 / 2}}{\mathrm{~V}[\mathrm{D}]}}^{1 / 2}\right)
$$

Broad- and narrow-sense heritability were calculated using Equations 20 (Falconer and Mackay 1996) and 21 (Mather and Jinks 1982):

$\mathrm{h}_{\mathrm{b}}^{2}=\frac{\mathrm{V}_{\mathrm{F} 2}-\mathrm{V}_{\mathrm{E}}}{\mathrm{V}_{\mathrm{F} 2}}=\frac{\mathrm{V}_{D}+\mathrm{V}_{H}}{\mathrm{~V}_{D}+\mathrm{V}_{H}+\mathrm{V}_{E}}$

$$
\mathrm{h}_{\mathrm{n}}^{2}=\frac{\mathrm{V}_{\mathrm{D}}}{\mathrm{V}_{\mathrm{F} 2}}=\frac{V_{D}}{\mathrm{~V}_{D}+\mathrm{V}_{H}+\mathrm{V}_{E}}
$$

The data normality test was performed using the SPSS software, and all other statistical and genetical analyses were conducted using the SAS software (Kang 2003). To compare the means of the studied generations, Tukey's test was used at $5 \%$ and $1 \%$ probability levels.

\section{Results and discussion:}

Examination of the normal distribution in the measured data based on skewness and kurtosis tests using the SPSS software indicated that the data related to all studied traits had a normal distribution (Table 1).

The results of the analysis of variance demonstrated a significant difference between the six generations for all studied traits at the probability level 1\% (Table 2); in other words, the genetic analysis and review of their inheritance were possible.

Evaluation of the mean and standard error of the traits (Table 3) revealed a significant difference between the means of parents and offspring for some traits, such as fruit length and width and seed length and width. Furthermore, the phenomenon of standard heterosis was observed for these traits, meaning that the average of the first generation (F1) for these traits was higher than the average parent. In the case of seed length, the value of the F1 generation obtained from the crossing of two parents was higher than 
the mean of the parents and even more valuable than the parents. Therefore, the phenomenon of heterobeltiosis (heterosis compared to the best parent) was observed for this trait. These results are very favorable considering the increase of fruit width and seed size. The value of this trait in $\mathrm{F} 2$ and $\mathrm{BC} 1$ generations was higher than that of both parents, while in the $\mathrm{BC} 2$ generation (backcrossing with the second parent), it was higher than the average of the parents but lower than the best parent value. According to the results, it is possible that the back-cross method transfers the desired characteristics to progenies. The average of the F2 generation compared to the F1 generation showed a decrease, which can be attributed to the effects of self-pollination and the existence of the phenomenon of inbreeding depression. Saad (2003) also confirmed these results by reporting the presence of heterosis in the fruit and seed traits of squash.

For the fruit shape index (fruit length to width ratio), considering that the optimal breeding goal is the round shape (i.e. shape index near to one), the offspring of the new generation has values of the shape index lower than those of the parents, which would be better due to higher yield (Ketsakul et al. 2020). Observation of the measurement results of this trait showed that the fruit shape index in the F1 generation (1.39) was decreased compared to the average of the parents (1.69), which was favorable according to the intended purpose. On the contrary, the value of this trait did not considerably decrease in the F2 generation compared to the F1 generation. In fact, in terms of achieving fruits with a round to oval shape, a favorable population was obtained. This superiority of offspring over the average of parents can indicate the existence of dominance or over-dominance effects in controlling this trait. The results of backcross generations demonstrated that the fruit shape index in $\mathrm{BC} 1$ was less than that in mid-parents; however, in BC2, it was more than that of mid-parents (Table 3). The fruit length of the first and second generations corresponded to the average of the parents. The value of this trait in the offspring of $\mathrm{BC} 1$ and $\mathrm{BC} 2$ was also less than that of mid-parents but more than that of parents with a lower value. Regarding the fruit width trait, the average of F1 generation was higher than that of parents and higher than that of the best parents. Therefore, the phenomenon of heterobeltiosis was observed for this trait in the current experiment. Moreover, in the offspring of the F2 generation not only there was no decrease compared to the F1 generation but also a higher value was obtained than the average of parents and even higher than parents with a higher value. This result is highly desirable considering that we aimed to reduce the length and increase the width of the fruit to reach the round shape of the fruit. This increase in value was also observed about $\mathrm{BC} 1$, while the results of $\mathrm{BC} 2$ were decreased compared to both parents.

In the case of seed thickness, the mean F1 obtained from the crossing of two parents was lower than the mean of the parents. Furthermore, the value of the F1 generation was less than the average of the parents, but it was close to the average and higher than that of parents. The value of this trait in the results 
of the $\mathrm{F} 2$ generation and the $\mathrm{BC} 1$ and $\mathrm{BC} 2$ was lower than the average of the parents and more than the 227 value of the parents with less seed thickness.

228 The results of the scaling tests showed that none of the scaling tests A, B, C and D was significant for the fruit shape index, seed length, seed width, and seed thickness traits, demonstrating that the effects of epistasis (non-allelic effects) did not play a crucial role in controlling the diversity of the mentioned traits. However, to ensure the results, it is better to calculate and test the effects of epistasis. On the contrary, for fruit length and width, the B-scaling test was significant at the level of 5\% probability, which probably indicates the presence of an additive $\times$ dominance interaction (Table 4).

Table 5 presents the genetic parameters controlling each of the studied traits. The results indicated that all genetic parameters were significant for fruit length, so that the dominance and dominance $\times$ dominance interaction effects and the other components were significant at $5 \%$ and $1 \%$ probability levels, respectively. In addition, the negative dominance effect and the positive dominance $\times$ dominance interaction effect for fruit length exhibited the presence of the duplicate epistasis effect of reducing dominance alleles. On the contrary, for fruit width, except for the additivex dominance interaction, which was significant at $1 \%$ probability level, the other effects were not significant. For the fruit shape index, the additive and the additive $\times$ dominance interaction effects were significant at $1 \%$ 242 probability level, and the other components were not significant.

The results for seed traits indicated that the additive and additive $\times$ dominance interaction effects were significant at $5 \%$ and $1 \%$ probability levels, respectively, while the other components were not significant. Simple effects and interactions were significant except dominant $\times$ dominant interaction. Conc Long \& ambiguous. Please rewrite more clearly.erning seed thickness, only the additive effect was significant at $1 \%$ probability level. The additive effect is investigated as a genetic effect in plant breeding, which is significant according to the researcher and corresponds to the results of the experiment. In addition, dominance genetic variations were significant for all studied mature fruit traits, except for average mature fruit diameter, since it was not significant.

Table 6 presents the evaluation of the components of variance, along with heritability and degree of dominance of each of the studied traits. The results indicated that concerning fruit length, fruit width, 253 seed length and seed thickness, the amount of additive variance more than the dominant variance 254 confirms the positive effect of selection on the breeding of these traits. However, in the case of the fruit 255 shape index, the additive variance was higher than the dominant variance, and regarding the seed width, 256 the two additives and dominance variance exhibited the same value. 
The results showed that about fruit length, fruit width and seed length, the environmental variance was less than the additive variance but greater than the dominance variance. The importance of additive and dominance variance regarding the fruit shape index and the seed thickness has been reported. This indicates the low effect of the environment on these traits in this experiment, but in the case of seed width, environmental variance revealed a greater effect than both additive and dominance variance did.

Regarding most of traits, broad-sense heritability was relatively high. Furthermore, high narrowsense heritability in some traits, such as fruit length and seed length, indicated that selection of the best individuals based on these traits could be successful, since the phenotype expresses almost the same genotype (Javanmard et al. 2018). These results were consistent with the findings obtained by Saad (2003), showing that the values of broad- and narrow- sense heritability were high for fruit length; this demonstrates the importance of additive genetic variance in the inheritance of this trait.

Concerning some traits, such as fruit shape index and seed width, relatively low narrow-sense heritability indicates the effect of the dominance component in controlling these traits, and hybrid seed production can be recommended to improve these traits. In other words, low narrow-sense heritability in 272 these traits confirms that there is less effect of additive variance and a positive effect of selection on these 273 traits (Rebolloza 2016). According to Al-Zabaee's reports (2006), broad-sense heritability was high for 274 their studied traits, such as fruit length and fruit diameter, while narrow-sense heritability was moderate.

The average degree of dominance for the fruit shape index and seed width was more than one, which probably indicates the presence of the over-dominance action of the genes controlling these traits; hence, selection of these traits was ineffective. In other words, it is better to use the hybrid production method to improve these traits in the studied population. Other researchers, in studying the gene action of different traits in squash, have reported similar results (Al-Ballat. 2008; Aruah et al. 2010; Najvot 2016). Moreover, the average degree of dominance for fruit length, fruit width, seed length and seed thickness varied from 0.27 to 0.94 , demonstrating the relative or partial dominance gene action as well as the importance of both additive and dominance effects in these traits. Accordingly, the selection can be made in early generations (Al-Zabaee 2006; Al-Ballat 2008; Hussien 2015).

Table 1. Data normality test

\begin{tabular}{ccccccc}
\hline & $\begin{array}{c}\text { Fruit } \\
\text { length }\end{array}$ & $\begin{array}{c}\text { Fruit } \\
\text { Width }\end{array}$ & Shape Index & $\begin{array}{c}\text { Seed } \\
\text { length }\end{array}$ & Seed width Seed thickness \\
\hline Skewness & 0.623 & 0.342 & 0.918 & -0.022 & -0.183 & 1.157 \\
kurtosis & -0.240 & -1.193 & 0.166 & -1.105 & 0.294 & 1.148 \\
\hline Sig (Kolmogorov-smirnov) & 0.20 & 0.20 & 0.052 & 0.20 & 0.20 & 0.18 \\
Sig (Shapiro-wilk) & 0.17 & 0.81 & 0.079 & 0.22 & 0.19 & 0.04 \\
\hline
\end{tabular}


Table 2. Analysis of variance for fruit and seed traits

\begin{tabular}{cccccccc}
\hline \multicolumn{7}{c}{ Mean squares } \\
\hline $\begin{array}{c}\text { Source of } \\
\text { Variation }\end{array}$ & df & Fruit length & Fruit width & Shape index & Seed length & Seed width & $\begin{array}{c}\text { Seed } \\
\text { thickness }\end{array}$ \\
\hline Replication & 2 & $0.098^{\mathrm{ns}}$ & $0.496^{\mathrm{ns}}$ & $0.006^{\mathrm{ns}}$ & $0.850^{*}$ & $0.198^{\mathrm{ns}}$ & $0.102^{\mathrm{ns}}$ \\
Generation & 5 & $19.163^{* *}$ & $9.462^{* *}$ & $0.297^{* *}$ & $2.312^{* *}$ & $1.199^{* *}$ & $0.515^{* *}$ \\
Error & 10 & 1.746 & 1.074 & 0.014 & 0.175 & 0.089 & 0.034 \\
\hline C.V.\% & & 6.180 & 7.356 & 7.889 & 2.619 & 3.280 & 8.005 \\
\hline
\end{tabular}

$288 \mathrm{~ns}, * * * *$ Non-significant and significant at 5 and $1 \%$ probability levels, respectively.

289

290

\begin{tabular}{ccccccc}
\hline Generation & $\begin{array}{c}\text { Fruit length } \\
(\mathrm{cm}) \\
\text { Mean } \pm \text { SE }\end{array}$ & $\begin{array}{c}\text { Fruit width }(\mathrm{cm}) \\
\text { Mean } \pm \text { SE }\end{array}$ & $\begin{array}{c}\text { Shape index } \\
\text { Mean } \pm \text { SE }\end{array}$ & $\begin{array}{c}\text { Seed length } \\
(\mathrm{mm}) \\
\text { Mean } \pm \text { SE }\end{array}$ & $\begin{array}{c}\text { Seed width } \\
(\mathrm{mm}) \\
\text { Mean } \pm \text { SE }\end{array}$ & $\begin{array}{c}\text { Seed thickness } \\
(\mathrm{mm}) \\
\text { Mean } \pm \text { SE }\end{array}$ \\
\hline P1 & $18.266 \pm 0.044$ & $13.666 \pm 0.12$ & $1.336 \pm 0.008$ & $14.703 \pm 0.042$ & $7.705 \pm 0.025$ & $1.930 \pm 0.029$ \\
P2 & $25.576 \pm 0.053$ & $12.433 \pm 0.06$ & $2.056 \pm 0.014$ & $15.709 \pm 0.043$ & $8.954 \pm 0.046$ & $3.105 \pm 0.028$ \\
F1 & $22.113 \pm 0.409$ & $15.950 \pm 0.579$ & $1.390 \pm 0.035$ & $17.152 \pm 0.142$ & $9.477 \pm 0.196$ & $2.247 \pm 0.039$ \\
F2 & $21.856 \pm 1.139$ & $14.653 \pm 0.833$ & $1.496 \pm 0.095$ & $16.123 \pm 0.512$ & $8.500 \pm 0.078$ & $2.134 \pm 0.189$ \\
BC1 & $19.445 \pm 0.827$ & $16.050 \pm 0.697$ & $1.216 \pm 0.104$ & $16.706 \pm 0.395$ & $9.111 \pm 0.078$ & $2.132 \pm 0.150$ \\
BC2 & $21.023 \pm 0.886$ & $11.803 \pm 0.193$ & $1.783 \pm 0.073$ & $15.503 \pm 0.363$ & $8.815 \pm 0.148$ & $2.450 \pm 0.174$ \\
\hline HSD $(0.01)$ & 4.904 & 3.847 & 0.452 & 1.554 & 1.068 & 0.693 \\
\hline HSD $(0.05)$ & 3.747 & 2.94 & 0.346 & 1.187 & 0.816 & 0.529 \\
\hline
\end{tabular}

291

292

\begin{tabular}{ccccccc}
\hline $\begin{array}{c}\text { Scaling } \\
\text { test }\end{array}$ & Fruit length & Fruit width & Shape index & Seed length & Seed width & Seed thickness \\
\hline A & $1.489^{\text {ns }}$ & $-2.484^{\text {ns }}$ & $0.294^{\text {ns }}$ & $-1.117^{\text {ns }}$ & $-0.907^{\text {ns }}$ & $-0.087^{\text {ns }}$ \\
B & $5.643^{*}$ & $4.777^{*}$ & $-0.12^{\text {ns }}$ & $1.444^{\text {ns }}$ & $0.846^{\text {ns }}$ & $0.452^{\text {ns }}$ \\
C & $0.678^{\text {ns }}$ & $-0.612^{\text {ns }}$ & $0.188^{\text {ns }}$ & $0.062^{\text {ns }}$ & $1.811^{\text {ns }}$ & $0.993^{\text {ns }}$ \\
D & $3.244^{\text {ns }}$ & $1.453^{\text {ns }}$ & $-0.007^{\text {ns }}$ & $0.018^{\text {ns }}$ & $-0.936^{\text {ns }}$ & $-0.314^{\text {ns }}$ \\
\hline
\end{tabular}

293 ns, ${ }^{* * *}$ : Non-significant and significant at 5 and $1 \%$ probability levels, respectively.

294 Significance levels are shown based on the t-test compared to table t.

295

296

297

Table 5. Estimation of genetic effects for different generations resulting from the Zucchini and Hull-less seeded

\begin{tabular}{ccccccc}
\hline $\begin{array}{c}\text { Genetic } \\
\text { parameter }\end{array}$ & Fruit length & Fruit width & Shape index & $\begin{array}{c}\text { Seed } \\
\text { length }\end{array}$ & Seed width & $\begin{array}{c}\text { Seed } \\
\text { thickness }\end{array}$ \\
\hline $\mathrm{m}$ & $28.411^{* *}$ & $15.956^{* *}$ & $1.683^{* *}$ & $15.279^{* *}$ & $6.460^{* *}$ & $1.889^{* *}$ \\
$\mathrm{~d}$ & $-3.655^{* *}$ & $0.616^{\mathrm{ns}}$ & $-0.360^{* *}$ & $-0.503^{*}$ & $-0.624^{* *}$ & $-0.587^{* *}$ \\
$\mathrm{~h}$ & $-19.919^{*}$ & $-5.206^{\mathrm{ns}}$ & $-0.453^{\mathrm{ns}}$ & $1.503^{\mathrm{ns}}$ & $5.045^{*}$ & $0.619^{\mathrm{ns}}$ \\
$\mathrm{i}$ & $-6.489^{\text {ns }}$ & $-2.906^{\mathrm{ns}}$ & $0.013^{\text {ns }}$ & $-0.072^{\text {ns }}$ & $1.870^{* *}$ & $0.628^{\text {ns }}$ \\
$\mathrm{j}$ & $4.154^{\mathrm{ns}}$ & $7.260^{* *}$ & $-0.413^{* *}$ & $3.412^{* *}$ & $1.752^{*}$ & $0.538^{\text {ns }}$ \\
$\mathrm{l}$ & $13.622^{*}$ & $5.200^{\mathrm{ns}}$ & $0.160^{\mathrm{ns}}$ & $0.370^{\mathrm{ns}}$ & $-1.929^{\mathrm{ns}}$ & $-0.261^{\mathrm{ns}}$ \\
\hline$x^{2}$ & $0.160^{\mathrm{ns}}$ & $0.035^{\mathrm{ns}}$ & $0.0019^{\mathrm{ns}}$ & $0.0004^{\mathrm{ns}}$ & $0.0092^{\mathrm{ns}}$ & $0.035^{\mathrm{ns}}$
\end{tabular}

298

ns, ${ }^{*}, * *$ Non-significant and significant at 5 and $1 \%$ probability levels, respectively. 
Table 6. Estimation of generation variance components for different generations resulting from the cross between

303 Zucchini and Hull-less seeded Pumpkin for the studied traits

\begin{tabular}{ccccccc}
\hline Variance component & Fruit length & $\begin{array}{c}\text { Fruit } \\
\text { width }\end{array}$ & $\begin{array}{c}\text { Shape } \\
\text { index }\end{array}$ & $\begin{array}{c}\text { Seed } \\
\text { length }\end{array}$ & Seed width & $\begin{array}{c}\text { Seed } \\
\text { thickness }\end{array}$ \\
\hline Additive variance & 1.698 & 0.719 & 0.002 & 0.356 & 0.009 & 0.028 \\
Dominance variance & 0.086 & 0.072 & 0.004 & 0.013 & 0.009 & 0.012 \\
Environmental variance & 0.172 & 0.353 & 0.001 & 0.023 & 0.016 & 0.003 \\
Narrow-sense heritability & 0.86 & 0.62 & 0.28 & 0.90 & 0.26 & 0.64 \\
Broad-sense heritability & 0.91 & 0.69 & 0.85 & 0.94 & 0.52 & 0.92 \\
The average degree of dominance & 0.31 & 0.44 & 2 & 0.27 & 1.41 & 0.94 \\
\hline
\end{tabular}

\section{REFERENCES:}

Al-Ballat, IA (2008) Breeding studies on summer squash crop (Cucurbita pepo L.). Dissertation, Faculty of Agriculture, Tanta University.

Al-Hamadany SYH, Al-Lelah WBA (2010) Estimating of heterosis and genetic variability in summer Squash (Cucurbita pepo L.). MJA 38(4): 27-37

Amaefula C, Agbo CU, Nwofia GE (2014) Hybrid vigor and genetic control of some quantitative traits of tomato (Solanum lycopersicum L.). OJGen 4: 30-39. DOI:10.4236/ojgen.2014.41005

Aruah C, Uguru M, Oyiga B (2010) Variations among some Nigerian Cucurbita landraces. Afr. J. Plant Sci 4: 374-386

Al-Zabaee HA (2006) Estimating genetic parameters by diallel crossing in summer squash. AJAS 4(1): $169-180$

Azizi F, Rezaie A, Saeidi G (2006) Generation means analysis to estimate genetic parameters for different traits in two crosses of Corn inbred lines at three planting densities. J. Agric. Sci. Technol 8: 153-169

Bernardo R (2002) Breeding for quantitative traits in Plants, 3rd edn. Stemma Press. 369 p.

Carle BR, Loy JB (1994) Heritability of seed size in hull-less seeded strains of Cucurbita pepo L. CGC Report 17:125-27. https://doi.org/10.21273/HORTSCI.29.4.245c

Decker-Walters D, Walters T (2000) Squash. In: Kiple KF, Ornelae KC (ed) The Cambridge world history of food. Cambridge University Press, pp 335-351.

Davoodi S, Olfati JA, HamidaOghli Y, Sabouri A (2015) Standard hetrosis in Cucurbita moschata and Cucurbita pepo interspecific hybrids. Int. J. Veg. Sci. 22(4):383-388. https://doi.org/10.1080/19315260.2015.1042993 
Elizabeth TM (2001) Plant spacing demonstration plot with Jack-o- Lantern and giant pumpkins. In: Morales MR. (ed.) Midwestern vegetable variety trial report for 2001. Purdue, pp 225-227.

Emerson RA (1910) The inheritance of sizes and shapes in plants. Am. Nat 44: 739-746.

Falconer DS, Mackey TFC (1996) Introduction to quantitative genetics 4rd edn. Department of Genetics Society of America, 479p.

Hazra P, Mandal AK, Dutta A K, Ram HH (2007) Breeding pumpkin (Cucurbita moshata Duch. ex Poir.) for fruit yield and other characters. Int. J. Plant Breed. 1:51-64

Hussien AH (2015) Nature of gene action and heterotic performance for yield and yield components in summer squash (Cucurbita pepo L.). Int. J. Plant prod, Mansoura University 6(1): 29 - 40. DOI: 10.21608/jpp.2015.49274

Hosseinzadeh Colagar A, Amjadi Souraki O (2012) Review of Pumpkin Anticancer Effects. Quran Medicine, MJIRI 1(4): 93-104. DOI:10.5812/QURANMED.8923

Hayman BI (1958) The separation of epistasis from additive and dominance variation in generation means. Heredity 12(3): 371-390

Javanmard T, Soltani Saleh-Abadi F, Bihamta MR (2018) Estimation of some genetic parameters through generation mean analysis in melon. Indian J. Agric. Res. 52: 619-624. DOI: 10.18805/IJARe.A-355

Jinks JH, Jones RM (1958) Estimation of components of heterosis. Genetics 43(2): 223-234.

Jeffrey C (1990) Systematic of the Cucurbitaceae. In: Bates DM, Robinson RW, Jeffrey C (ed) Biology and Utilization of the Cucurbitaceae, Cornel University Press, Ithaca, pp 3-9.

Kang MS (2003). Handbook of formulas and software for plant geneticists and tree breeders. Food Products Press. 69p.

Kearsey MJ, Pooni HS (1996) The genetic analysis of quantitative traits. Chapman and Hull. http://dx.doi.org/10.1007/978-1-4899-4441-2

Ketsakul S, Imsabai W, Tangtrakulwanich K, Auvuchanon A (2020) Identification of genes controlling fruit shape in thai pumpkin (Cucurbita moschata Duch.). IJAT 16(3): 629-640

Latifi M, Barimavandi A, Sedaghathoor S Lipayi SR (2012) Sowing date and plant population effects on seed yield of Cucurbita pepo. Int J Agric Biol 14: 641-644 
Mather K, Jinks JL (1982) Biometrical Genetics. (Third Ed.).Champan and Hall. 398p. https://doi.org/10.1002/bimj.4710260111

Mitra J (2001) Genetics and genetic improvement of drought resistance in a crop plant. Curr. Sci. 80(6): 758-763.

Navjot K (2018) Genetic studies of yield and its component traits using generation mean analysis in Summer squash (Cucurbita pepo subsp. pepo). Veg. Sci. 45(2): 154-160

Paris HS (2008) Summer Squash, pp 351-379.In: J. Prohens, and F. Nuez (eds.). Handbook of Plant Breeding.Vegetables I. Springer, Heidelberg.

Paris HS, Brown RN (2005) The Genes of Pumpkin and Squash. Hort Science 40:1620-1630. https://doi.org/10.21273/HORTSCI.40.6.1620

Paris HS, Nerson H (2003) Seed Dimensions in the Subspecies and Cultivar-groups of Cucurbita pepo. Genetic. Resour. Crop Evol 50: 615-625. DOI:10.1023/A:1024464831595

Rebolloza-Hernández H, Castillo-Gutiérrez A, Carapia-Ruíz VE (2016) Estimation of genetic parameters and selection of S1 lines in a segregating population of tropical maize. Rev. Mexicana Cienc. Agríc 7(8):8, 1893-1904.

Saad MS (2003) Inheritance of some economical traits in squash (Cucurbita pepo L.). Dissertation, Faculty of Agriculture, Mansoura University, Egypt.

Schaefer H, Renner SS (2011) Phylogenetic relationships in the order Cucurbitales and a new classification of the gourd family (Cucurbitaceae). Taxon, 60: 122-138. DOI:10.1002/tax.601011

Savage JA, Haines DF, Holbrook NM (2015) The making of giant pumpkins: how selective breeding changed the phloem of Cucurbita maxima from source to sink. Plant, Cell \& Environment 38 (8):1543-1554. DOI: $10.1111 /$ pce.12502

Sajed MA, Hosseini-Moghaddam H, Yazdani D, Ahmadi-Aval P (2002) Effect of plastic mulch of soil, plant spacing and $\mathrm{P}$ and $\mathrm{K}$ fertilization level on growth and seed and oil yield of medicinal Squash. Proceedings of Iranian Conference on Medicinal Herbs. 13-15 Feb. Tehran, Iran. pp.188.

Sinnott GW (1936) A developmental analysis of inherited shape differences in cucurbit fruits. Am.Nat. 70: 245-254. DOI: $\underline{10.1086 / 280661}$

Wang YH, Behera TK, Kole C (2012) Genetics, Genomics and Breeding of Cucurbits. Taylor \& Francis Group. Boca Raton, FL. https://doi.org/10.1201/b11436 